\title{
Salmonella Serovars in Laying Hen Flocks and Commercial Table Eggs from a Region of São Paulo State, Brazil
}

http://dx.doi.org/10.1590/1516-635x160257-62

\section{-Author(s)}

Freitas Neto OC de

Galdino VMCA

Campello P L'

Almeida AM de'

Fernandes SA"

Berchieri Júnior $A$

Department of Veterinary Pathology, Faculty of Agriculture and Veterinary Sciences, Univ. Estadual Paulista, Jaboticabal, São Paulo, Brazil.

" Bacteriology section, Adolfo Lutz Institute, São Paulo, São Paulo, Brazil.

\section{ABSTRACT}

Salmonella spp. is the main originator of human foodborne diseases worldwide and is mainly transmitted by food containing eggs. In Brazil, as a result of the lack of studies and data collection very little is known about the prevalence of Salmonella spp. in laying hen flocks and commercial table eggs. Consequently the present study was elaborated and aimed at generating data about Salmonella spp. in part of the Brazilian egg production chain. Eight flocks of day-old chicks, eight flocks of adult laying hens (four vaccinated with bacterin against Salmonella Enteritidis and four unvaccinated) and commercial table eggs from four supermarkets were examined. Salmonella spp. was isolated in $50 \%$ of the newly hatched chicks, $25 \%$ of the adult flocks and $1.5 \%$ of egg samples examined. S. enterica subsp. enterica 4,12:r:-, S. Mbandaka, S. enterica subsp. enterica 6,7: z10:-, S. Enteritidis and S. Havana were the serovars isolated in birds. In commercial table-eggs $S$. Mbandaka, S. enterica subsp. enterica 6,7: z10:- and S. Braenderup were isolated. These results show that Salmonella spp. is present in laying hen flocks and consequently in eggs destined for human consumption. Probably, some of the Salmonella serovars are being introduced in egg farms by vertical via.

\section{INTRODUCTION}

Samonella spp. is a major zoonotic pathogen being the originator of several foodborne diseases outbreaks worldwide each year. These microorganisms may cause human suffering as well as economic losses to food production and to the food industry (Foley et al., 2008; IFAH, 2012). Poultry and eggs remain the major sources of Salmonella spp. in developed countries. Eggs and dairy products accounted for $42 \%$ of the outbreaks caused by Salmonella spp. in Europe (EFSA, 2009). According to the Brazilian health surveillance service, from 1999 to 2009, 6,349 foodborne diseases outbreaks were notified, and eggs and foods containing egg were responsible for $15 \%$ of them (COVEH, 2009).

There are over 2,600 Salmonella serovars identified but about 90 are responsible for human and animal salmonellosis (EFSA, 2009, CDC, 2011). In 2009, Enteritidis, Typhimurium, Newport, Javiana and Heidelberg were the five most frequently reported Salmonella serovars from human sources in the United States (CDC, 2011). Food of animal origin is the main source of Salmonella spp. for human beings (Pires et al., 2010). Over the last decades, there has been an increase in reported cases of human salmonellosis, making the public health authorities focus attention on controlling Salmonella spp. in livestock, poultry, and their products (Newell et al., 2010).

To take measures able to reduce human foodborne salmonellosis is essential. It is also important to quantify the burden of human illness and 
also to identify the sources, route of infection and the main serovars involved (Pires et al., 2010). Considering eggs and food containing eggs as the major sources of human foodborne salmonellosis, measures and control programs to reduce Salmonella spp. and minimize the human exposure must be addressed to chicken farms (Barrow, 2007; Gast, 2007). However, to elaborate a control program it is necessary to know the prevalence and epidemiology of the main Salmonella serovars in chicken flocks.

Little is known about prevalence of Salmonella serovars in Brazil. A piece of work was done by Zancan et al. (2000) who analysed meconium samples from transport cardboard boxes of chicks. According to this study, Salmonella Heidelberg and Mbandaka were detected in broiler breeder chicks. Meanwhile, Enteritidis, Mbandaka and Cerro were isolated in laying hen chicks. Moreover, Kanashiro et al. (2005) isolated S. Enteritidis, Heidelberg, Kentucky, Infantis, Mbandaka, Typhimurium, Senftenberg and other serovars in samples of faeces, meconium and eggs of breeders and broilers of several regions of Brazil from 1997 to 2004. S. Enteritidis was the most recovered serovar in the mentioned study.

Although few studies on the prevalence of Salmonella serovars have been carried out in Brazil (Zancan et al., 2000; Kanashiro et al., 2005; Fernandez et al., 2006; Kottwitz et al., 2008), the information about these microorganisms in humans, animals and food of animal origin are not updated and remain underestimated. The present study was carried out in order to generate data which could support the elaboration of new Salmonella spp. control programs for the poultry industry or to help in evaluating the existing ones. This study aimed at surveying for Salmonella serovars in flocks of newly hatched chicks, adult commercial laying hens and a representative amount of commercial table-eggs from supermarkets of a region of Sao Paulo state, Brazil.

\section{MATERIAL AND METHODS}

\section{Samples and sampling}

The presence of Salmonella spp. was assessed in flocks of laying hens from eight farms (A, B, C, D, E, F, $\mathrm{G}$ and $\mathrm{H}$ ) and in commercial table-eggs commercialized by four supermarkets (I, J, K and L); all establishments from the same region of São Paulo State, Brazil.

To investigate whether the chicks were getting farm infected with Salmonella spp., samples of meconium from eight newly hatched chick flocks (one flock from each farm) were collected from transport boxes following the methodology described by Zancan et al. (2000). Each flock had about 3,000 birds and were transported in cardboard boxes with 100 birds each. In total, 240 boxes were examined using a large gauze swab moistened in $1 \%$ buffered peptone water (BPW) (Oxoid@ CM0509). Swabs from five boxes were placed into sterile glass with $225 \mathrm{~mL}$ of BPW and corresponded to one sample. Samples were taken to the laboratory under refrigeration.

Salmonella spp. was also searched in faecal samples of other eight flocks (four vaccinated with oil-emulsion bacterin against $S$. Enteritidis and four unvaccinated) of adult laying hens (aged twenty-three to thirty-eight weeks). Each chicken house was divided into four parts. Fresh samples of cecal faeces from each part were collected under the cages using sterile swabs moistened in BPW, which were placed into sterile glass and corresponded to one "pool" of samples. In total, sixty-four pools of samples, taken at different times from the eight flocks, were stored in sterile glasses with $225 \mathrm{~mL}$ of BPW and transported to the laboratory under refrigeration.

A total of 1,700 eggs from four supermarkets (I, $\mathrm{J}, \mathrm{K}$ and $\mathrm{L}$ ) of the same region were examined. Each egg sample consisted of five eggs (shell and contends); a total of 340 samples were examined. Eggs were bought in packages of a dozen at different moments $(1,2,3$ and 4).

\section{Sample processing}

\section{Bacteriological exams}

Glasses containing the samples in BPW were left at room temperature for one hour, followed by overnight incubation at $37^{\circ} \mathrm{C}$. Then, $2.0 \mathrm{ml}$ of the BPW was transferred to tube containing $20 \mathrm{ml}$ of selenite (Oxoid, CM 395) plus Novabiocin at concentration of $40 \mathrm{mg} / \mathrm{L}$ (Merial, 8041706) (SN) and Tetrationate (Biolife, 402125) plus Novobiocin (40 mg/L) broths and $0.2 \mathrm{ml}$ to $20 \mathrm{~mL}$ of Rappaport - Vassiliadis (RV) (Oxoid, CM 669) broth. Broths were incubated overnight at $37{ }^{\circ} \mathrm{C}$ (Davies \& Wray, 1994). After removed from the package, "pools" of 5 eggs were placed into sterile glass jars, broken and homogenised with a sterile wooden stick and then incubated overnight at $37^{\circ} \mathrm{C}$. After that, amounts of 2.0, 2.0 and $0.2 \mathrm{~mL}$ of this content were inoculated into tubes containing $20 \mathrm{~mL}$ of SN, TN and RV broths, respectively, and were then incubated overnight at $37{ }^{\circ} \mathrm{C}$. Subsequently, broths from all samples were plated onto the following mediums: Brilliant Green agar (Oxoid, CM 0263), Mac 
Conkey agar (Oxoid, CM 0115) and XLT4 agar (Difco, 223420). Plates were incubated overnight at $37^{\circ} \mathrm{C}$. From each plate, five typical colonies were inoculated in triple Sugar Iron agar (Oxoid, CM 277) and in Lysine Iron agar (Oxoid, CM 381), which were incubated overnight at $37{ }^{\circ} \mathrm{C}$ and submitted to serology using polyvalent sera against $\mathrm{O}$ and $\mathrm{H}$ Salmonella antigens (Probac). Isolates were sent to Adolfo Lutz Institute, São Paulo, Brazil, for complete identification and serotyping.

\section{RESULTS AND DISCUSSION}

Salmonella spp. was isolated from transport boxes used to deliver newly hatched chick flocks in four different farms. S. Mbandaka was isolated in flocks of farms B, C, F and G; Salmonella enterica subspecies. enterica 4,12: $r$ : - was recovered in flock from farm $C$ and Salmonella enterica subsp. 6,7 enterica: Z10: - on farm G (Table1).

Table 1 - Salmonella serovars isolated in meconium samples from transport boxes of newly hatched chicks.

\begin{tabular}{|c|c|}
\hline $\begin{array}{c}\text { Flocks of newly hatched chicks } \\
\text { from FARMS }\end{array}$ & serovars \\
\hline$A$ & - \\
\hline B & Salmonella Mbandaka \\
\hline C & $\begin{array}{l}\text { Salmonella Mbandaka } \\
\text { S. enterica subsp. enterica 4, 12: r: - }\end{array}$ \\
\hline D & - \\
\hline $\mathrm{E}$ & - \\
\hline $\mathrm{F}$ & Salmonella Mbandaka \\
\hline G & $\begin{array}{l}\text { Salmonella Mbandaka } \\
\text { S. enterica subsp. enterica 6, 7: z10: - }\end{array}$ \\
\hline $\mathrm{H}$ & - \\
\hline
\end{tabular}

It is known that when poultry become infected with Salmonella spp. at the beginning of life is more difficult to control because newly hatched chicks are very susceptible, and they may shed this bacterium in high amount and for long periods (Barrow et al., 1988). Although many efforts have been done in breeder farms and hatcheries, Salmonella spp. still can be found in newly hatched chicks inside the hatchery or at the moment of arrival on the farm (Cox et al., 1991; Cox et al., 2000; Snow et al., 2008). Reports have shown that the detection of Salmonella spp. may vary from $11 \%$ to $77 \%$, being S. Enteritidis the most common one (Cox et al., 1990; Zancan et al.,2000; Cox et al., 1991; Gama et al., 2003; Rocha et al., 2003). The work done by Zancan et al. (2000) that reported positive results in day-old bread birds, suggesting that also grand-parent flocks would be infected by Salmonella serovars calls
Salmonella Serovars in Laying Hen Flocks and Commercial Table Eggs from a Region of São Paulo State, Brazil

our attention. In the present study, four of the eight farms received chicks infected with four Salmonella spp. showing that the control program in breeder farms and hatcheries should be improved.

S. Havana was isolated in cecal faeces from flocks of farms C and G; meanwhile S. Enteritidis was detected only in flock from farm $G$ (Table 2). Faeces are the potential vehicle in transmitting Salmonella spp. to birds and are also an important source of contamination for eggs (Gast \& Beard, 1992, Gast, 2003). Infected birds can shed intermittently about $10^{8}$ cells of Salmonella spp. per gram of feces (Bryan \& Doyle, 1995). In this work, $25 \%$ of the adult flocks were shedding Salmonella spp. Similar results were reported by Salles et al. (2008), who detected Salmonella spp. in $25 \%$ of the inspected flocks and by Kottwitz et al. (2008) that detected these microorganisms in $23 \%$ of examined flocks. These findings are higher than those reported by Castellan et al. (2004) who found Salmonella spp. in $10.5 \%$ of laying hen flocks in The United States and also higher than those presented by Snow et al. (2007), who isolated S. Enteritidis, Typhimurium, Mbandaka, Havana and other serovars in $11.7 \%$ of commercial flocks in the United Kingdom. It is known that factors such as weather, geographic location of the farm, farming conditions and management of the flock can influence the prevalence of Salmonella spp. in poultry (Khakharia et al., 1997; Angulo \& Swerdlow, 1999).

Table 2 - Salmonella serovars isolated in cecal faeces of layers in flocks vaccinated and unvaccinated against Salmonella Enteritidis.

\begin{tabular}{cc} 
Flocks of adult & Serovars \\
laying hens from & \\
FARMS & - \\
A & - \\
B & Salmonella Havana \\
D & - \\
E & - \\
F & - \\
G & Salmonella Enteritidis \\
H & Salmonella Havana \\
\hline
\end{tabular}

- = Absence of Salmonella spp.

There are few reports mentioning the isolation of S. Havana in faeces of commercial layers (Hussein et al., 2010), even though it was isolated from faeces of two flocks examined in the present study. S. Havana was isolated from poultry food and supplements (Berchieri Junior et a., 1989; Okamura et al., 2001, Davies \& Breslin, 2004), and this could be the source of contamination for the chickens in the present 
study. Hygiene and biosecurity in addition to the administration of an appropriate form of oil emulsion bacterium against $S$. Enteritidis in flocks of farms $A, B$, $C$ and $D$ could be some of the factors that contributed to the absence of this serovar. In a study conducted in Japan, S. Enteritidis was isolated in several samples of faeces, eggs and the environment from farms containing vaccinated and unvaccinated flocks and the percentage of isolation was lower in flocks where the oil-emulsion bacterin against $S$. Enteritidis was administered (Toyota-Hanatani et al., 2009). Freitas Neto et al. (2008) also reported reductions in shedding of $S$. Enteritidis and egg contamination in laying hens experimentally vaccinated with bacterin. In the present study, the isolation of $S$. Havana in faeces of birds from farm $C$, vaccinated against $S$. Enteritidis, demonstrates a lack of cross protection between these serovars.

In this study, three of the four supermarkets had at least one egg sample positive for Salmonella spp. Among 340 egg samples examined, five (1.47 \%) were contaminated. It was isolated $S$. Mbandaka and S. enterica subspecies enterica 6,7: z10:- in the supermarkets I and J, and S. Braenderup in the supermarket L. No Salmonella spp. was recovered in egg samples from supermarket $\mathrm{K}$ (Table 3 ).

Table 3 - Salmonella serovar isolated from table egg samples from four supermarkets.

\begin{tabular}{|c|c|c|c|c|c|}
\hline \multirow{2}{*}{$\begin{array}{l}\text { Sample } \\
\text { collection }\end{array}$} & & \multicolumn{3}{|c|}{ SUPERMARKETS } & Serovar \\
\hline & I & J & K & L & \\
\hline 1 & + & - & - & - & S. Mbandaka \\
\hline 2 & + & - & - & + & $\begin{array}{l}\text { S. Mandaka; S. enterica subspecies } \\
\text { enterica } 6,7: \text { z10:- ; S. Braenderup }\end{array}$ \\
\hline 3 & + & + & - & - & $\begin{array}{l}\text { Salmonella spp.; S. Mandaka; S. } \\
\text { enterica subspecies enterica 6,7: z10:- }\end{array}$ \\
\hline
\end{tabular}

\begin{tabular}{llllll}
4 & - & - & - & - & - \\
\hline
\end{tabular}

Lower percentages of Salmonella spp. in eggs have been described. For instance, Ebel \& Schosser (2000) reported $0.005 \%$ of contamination in eggs examined in The United States. In European countries, the percentage of Salmonella spp. in eggs was about $0.8 \%$ (EFSA, 2010). On the other hand, percentages of Salmonella spp. similar to what was found in the present study have also been reported by Humphrey (1994) and Okamura et al. (2001). According to Humphrey (1994) and Gast (2003) there are many factors that can contribute to variations in the percentages of Salmonella spp. in eggs. Factors such
Salmonella Serovars in Laying Hen Flocks and Commercial Table Eggs from a Region of São Paulo State, Brazil

as the sample size, season of sampling, bacteriologic method adopted for examination and the bacterial load present in eggs would be some of them.

During the 2000s, S. Enteritidis was one of the most frequent serovars associated with worldwide outbreaks of diseases transmitted by food containing poultry or eggs (EFSA, 2007; CDC, 2011; Fernandes et al., 2006; O'Brien, 2012). Although, in lower numbers, reports of human foodborne salmonellosis caused by S. Havana, S. Mbandaka, S. Braenderup (other serovars isolated in this study) have been described (Taunay et al. 1996; Tavechio et al. 1996; Fernandes et al., 2006; CDC, 2011). Therefore, their presence in table eggs and laying hen flocks represent risk for public health.

The results of this study demonstrate that, in addition to $S$. Enteritidis, other serovars are present in commercial laying hens and table eggs. As could be noticed in our results, some of these serovars are possibly being introduced in the egg production chain by infected newly hatched chicks when they arrive at the farm. In order reduce the prevalence of Salmonella serovars in the laying hen flocks and eggs, the control programs should be improved not only in egg farms but also in hatcheries and breeder farms.

\section{ACKNOWLEDGEMENTS}

The authors would like to thank FAPESP and CNPq for financial support and the Adolfo Lutz Institute of São Paulo, Brazil, for complete identification and serotyping of the isolates.

\section{REFERENCES}

Angulo FJ, Swerdlow DL. Epidemiology of human Salmonella enterica serovar enteritidis infections in the United States. In: Saeed AM, Gast RM, Potter MR, editors. Salmonella enterica serovar enteritidis in humans and animals: epidemiology, patho- genesis, and control. Ames: lowa State University Press; 1999. p. 33-41.

Barrow PA, Simpson JM, Lovell MA. Intestinal colonization in the chicken by food- poisoning Salmonella serotypes: microbial characteristics associated with faecal excretion. Avian Pathology 1988;17:571-588.

Barrow PA. Salmonella infections: immune and non-immune protection with vaccines. Avian Pathology 2007;36:1-13.

Berchieri Júnior A, Adachi SY, Calzada CT, Paulillo AC, Schoken-Iturrino RP, Tavechio AT. Farinha de carne como fonte de Salmonella em granja avícola. Pesquisa Veterinária Brasileira 1989;9(1):9-12.

Bryan FL, Doyle MP. Health risks and consequences of Salmonella and Campylobacter jejuni in raw poultry. Journal of Food Protection 1995;58(3): 323-344.

CDC. Centers for Diseases Control and Prevention. Salmonella: annual summary 2009. Georgia: US Department of Health and Human Services; $2011.96 p$. 
Cox NA, Bailey, JS, Mauldin JM. Extent of Salmonellae contamination in breeder hatcheries. Poultry Science 1991;70:416-418.

Cox NA, Berrang ME, Cason JA. Salmonella penetration of egg shells and proliferation in broiler hatching eggs - a review. Poultry Science 2000;79:1571-1574.

COVEH. Coordenação de Vigilância das Doenças de Transmissão Hídrica e Alimentar. Análise epidemiológica dos surtos de doenças transmitidas por alimentos no Brasil, 1999 - 2009. Ministério da Saúde, Secretaria de Vigilância em Saúde 2009. Disponível em: http://portal.saude.gov. br/portal/arquivos/pdf/analise_ep_surtos_dta_brasil_2009.pdf

Davies RH, Breslin M. Observation on Salmonella contamination of eggs from infected commercial laying flocks where vaccination for Salmonella enterica serovar enteritidis has been used. Avian Pathology 2004;33(4): 133-144.

Ebel E, Scholosser W. Estimating the annual fraction of eggs contaminated with Salmonella Enteritidis in the United States. International Journal of Food Microbiology 2000;61:51-62.

European Food Safety Authority. The community summary report on trends and sources of zoonoses, zoonotic agents, antimicrobial resistance and foodborne outbreaks in European Union in 2006. EFSA Journal 2007; $130: 28-80$

European Food Safety Authority. The Community Summary Report on foodborne outbreaks of the European Union in 2007. The EFSA Journal, n. 271, 2009.

European Food Safety Authority Scientific opinion on a quantitative estimation of the public health impact of setting a new target for the reduction of Salmonella in laying hens. The EFSA Journal 2010; 8 (4):1546.

Fernandes AS, Tavechio AT, Ghilardi ACR, Dias AMG, Almeida IAZC, Melo LCV. Salmonella serovars isolated from humans in São Paulo State, Brazil. Revista do Instituto de Medicina Tropical de São Paulo 2006;48(4):179-184

Freitas Neto OC, Lopes Mesquita A, Paiva JB, Zotesso F. Berchieri Junior A. Control of Salmonella enterica serovar Enteritidis in laying hens by inactivated salmonella enteritidis vaccines. Brazilian Journal of Microbiology 2008,39:390-396.

Foley SL, Lynne AM, Nayak R. Salmonella challenges: prevalence in swine and poultry and potential pathogenicity of such isolates. Journal of Animal Science 2008;86 (14):149-162

Gama NMSQ, Berchieri Júnior A, Fernandes SA. Occurrence of Salmonella sp in laying hens. Brazilian Journal of Poultry Science 2003;5 (1):15-21.

Gast RK, Beard CW. Detection and enumeration of Salmonella enteritidis in fresh and stored eggs laid by experimentally infected hens. Journal of Food Protection 1992;55 (3):152-156.

Gast RK. Salmonella infections. In: Calnek BW, Barnes HJ, Bear CW, editors. Diseases of poultry. 11th ed. Ames: lowa University Press; 2003. p. 567- 613 .

Gast RK. Serotype-specific and serotype-independent strategies for preharvest control of food-borne Salmonella in poultry. Avian Disease 2007; 51;817-828.

Humphrey TJ. Contamination of eggs Shell and contents with Salmonella enteritidis: a review. International of Journal of Food Microbiology 1994;21(1):31-40.

Hussein AAEL, Nor Elmadiena MM, Elsaid SM, Siddig MAM, Muckle CA, Cole L, Wilkie E, Mistry E. Prevalence of Salmonella enterica subspecies enterica Serovars in Khartoum State, Sudan. Research Journal of Microbiology 2010;5:966-973.
International Federation for Animal Health. The Costs of Animal Disease Oxford Analytica; 2012. 37p.

Kanashiro AMI, Stoppa GFZ, Cardoso ALSP, Tessari ENC, Castro AGM Serovars of Salmonella spp. isolated from broiler chickens and commercial breeders in diverse regions in Brazil from July 1997 to December 2004. Brazilian Journal of Poultry Science 2005;7:195-198.

Khakharia R, Woodward D, Johnson WM, Poppe C. Salmonella isolated from humans, animals and others sources in Canada. Epidemiology and Infection 1997;119:15-23.

Kottwitz LBM, Back A, Leão JA, Alcocer I, Karan M, Oliveira TCRM Contaminação por Salmonella spp. em uma cadeia de produção de ovos de uma integração de postura comercial. Arquivo Brasileiro de Medicina Veterinária e Zootecnia 2008;60(2): 496-498.

Newell DG, Koopmans M, Verhoef L, Duizer E, Aidara-Kane A, Sprong $H$, Opsteegh M, Langelaar M, Threfall J, Scheutz F, van der Giessen J, Kruse H. Food-borne diseases - the challenges of 20 years ago still persist while new ones continue to emerge. International of Journal of Food Microbiology 2010;139(1):3-15

O'Brien SJ. The "Decline and Fall" of Nontyphoidal Salmonella in the United Kingdom. Clinical Infectious Diseases; 2012.

Okamura M, Kamijima Y, Miyamoto T, Tani H, Sasai K, Baba E. Differences among six Salmonella serovars in abilities to colonize reproductive organs and to contaminate eggs in laying hens. Avian Diseases 2001;45(1):61-69.

Pires SM, Vigre H, Makela P, Hald T. Using Outbreak Data for Source Attribution of Human Salmonellosis and Campylobacteriosis in Europe. Foodborne Pathogens and Disease 2010;7:1351-1361.

Rocha PT, Mesquita AJ, Andrade MA, Louly PR, Nascimento MN. Salmonella spp. em forros de caixa de transporte e órgãos de pintos de um dia. Arquivo Brasileiro de Medicina Veterinária e Zootecnia 2003;55(6):672-676.

Salles RPR, Teixeira RSC, Siqueira AA, Silva EE, Castro SB, Cardoso WM. Monitoramento bacteriológico para Salmonella spp. em poedeira comercial na recria e produção de empresas avícolas da região metropolitana de Fortaleza, CE, Brasil. Ciência Animal Brasileira 2008:9(2):427-432.

Snow LC. Davies RH, Christiansen KH, Carrique-Mas JJ, Cook AJC, Teale CJ, Evans SJ. Survey of the prevalence of Salmonella on commercial broiler farms in the United Kingdom. Veterinary Record 2008;163(22):649-654.

Snow LC, Davies RH, Christiansen KC, Carrique-Mas JJ, Wales AD, O'Connor JL, Cook AJC, Evans SJ. Survey of Salmonella prevalence on commercial layer farms in the United Kingdom. Veterinary Record 2007;161(14):471-476.

Taunay AE, Fernandes AT, Tavechio BC, Neves BC, Dias AMG, Irino K. The role of public health laboratory in the problem of salmonellosis in São Paulo, Brazil. Revista do Instituto de Medicina Tropical de São Paulo 1996;38(2):119-127.

Tavechio BC, Fernandes AT, Neves BC, Dias AMG, Irino K. Changing patterns of Salmonella serovars: Increase of Salmonella Enteritidis in São Paulo, Brazil. Revista do Instituto de Medicina Tropical de São Paulo 1996;38(5): 315-322

Toyota-Hanatani Y, Ekawa T, Ohta H, Igimi S, Hara-Kudo Y, Sasai K, Baba E. Public health assessment of Salmonella enterica serovar Enteritidis inactivated-vaccine treatment in layer flocks. Applied and Environmental Microbiology 2009; 75(4):1005-1010.

Zancan FT, Berchieri Junior A, Fernandes SA, Gama NMSQ. Salmonella spp investigation in transport boxes of day-old birds. Brazilian Journal of Microbiology 2000;31:229-232. 
